\title{
REVOLÚCIA 1848/1849 A SLOVENSKÉ NÁRODNÉ HNUTIE V MÚZEJNEJ PREZENTÁCII
}

\section{L'UBOŠ KAČÍREK}

\section{ABSTRAKT/ABSTRACT:}

Príspevok približuje múzejnú prezentáciu formovania modernej slovenskej štátnosti a symbolov dnešnej Slovenskej republiky. Jej počiatky siahajú do obdobia revolúcie 1848/1849, kedy vznikajú národné symboly Slovákov, dnes symboly Slovenskej republiky, ako aj počiatky slovenského parlamentarizmu a vojenskej tradície. Predstavuje osobnosti, ktoré sa podielali na formovaní národného hnutia v tomto období s dôrazom na zbierkové predmety pochádzajúce $\mathrm{z}$ tohto obdobia a ich múzejnú prezentáciu, ktorá bola ovplyvnená politickou situáciou na území Československa.

The revolution in 1848/1849 and the Slovak national movement in museum presentation

The contribution outlines museum presentation of the formation of modern Slovak statehood and the symbols of today's Slovak Republic. Its beginnings go back to the period of the revolution in 1848/1849 which saw the emergence of the national symbols of Slovaks - today symbols of the Slovak Republic - as well as the beginning of the Slovak military tradition. It presents the prominent figures who contributed to the formation of the national movement in that period with an accent on collection items originating from that time and their museum presentation which was influenced by the political situation within Czechoslovakia.

\section{KLUÚČOVÉ SLOVÁ/KEYWORDS:}

revolúcia 1848/1849 - národné a štátne symboly - slovenská politická reprezentácia - Slovenská národná rada

revolution in 1848/1849 - national and state symbols - Slovak political representation - Slovak National Council

Hoci od revolúcie 1848/1849 prešlo 170 rokov, je pevnou súčastou historickej pamäte obyvatelov západnej a strednej Európy. Aj napriek tomu, že bola prekrytá novými udalostami, ktoré, na prvý pohl'ad, výraznejšie rezonujú v súčasnej spoločnosti, pravidelne si - vedome i nevedome - pripomíname udalosti revolúcie 1848/1849 $\mathrm{v}$ habsburskej monarchii, Uhorsku a z pohladu národnouvedomovacieho procesu Slovákov. Konajú sa vedecké podujatia, pripomíname si osobnosti, ktoré boli jej aktívnymi účastníkmi. Významným faktorom na formovanie historickej pamäti je štátna moc, resp. politický systém, ktorí sa podielajú na konštruovaní oficiálnej pamäti ako súčasti štátnej ideológie. Oficiálna pamät sa prejavuje o. i. v oslave štátnych sviatkov či pamätných dní, pamätníkoch, pomenovaniach ulíc či sprístupňovaní múzejných expozícií. Zároveň však ovplyvňuje aj vedeckú pamät, ked' môže viesṫ až k deformovaniu objektívneho pohladu na historické udalosti. ${ }^{1}$

1 Bližšie napríklad GABZDILOVÁ, Soňa. Historická pamät - jeden z formatívnych fenoménov interpretácie dejín. In BAČOVÁ, Viera (ed.). Historická pamät a identita. Košice: Spoločenskovedný ústav Slovenskej akadémie vied, 1996, s. 29-41
Parafrázujúc Maurica Halbwachsa, aj takouto formou sa upevňuje $\mathrm{v}$ rámci formovania historickej pamäti kontinuita medzi svedkami a hýbatel'mi daných udalostí a súčasnou spoločnostou, ktorá sa zaujíma o tieto historické udalosti. ${ }^{2}$ V tomto období sa zrodili slovenské národné symboly - národné farby, zástava a erb, dnes štátne symboly Slovenskej republiky. ${ }^{3}$ Národný pohyb organizovala Slovenská národná rada (d’alej SNR), založená 16. 9.1848 vo Viedni, od ktorej odvíja svoju kontinuitu aj slovenský parlament - Národná rada Slovenskej republiky. ${ }^{4} \mathrm{Na}$ jej čele stáli

alebo MANNOVÁ, Elena. "Meruôsmy" v médiách spomínania a zabúdania. In MACHO, Peter a kol. Revolúcia 1848/49 a historická pamät'. Bratislava: Historický ústav Slovenskej akadémie vied, 2012, s. 11-34.

2 HALBWACHS, Maurice. Kolektivní pamět. Praha: SLON, 2009, s. 124

3 Bližšie pozri: ŠKVARNA, Dušan. Začiatky moderných slovenských symbolov. K vytváraniu národnej identity od konca 18. do polovice 19. storočia. Banská Bystrica: Univerzita Mateja Bela, Fakulta humanitných vied, 2004. Podrobnejšie v kapitole č. 5. Revolučná kríza 1848-1849 a národné symboly, s. 81-102 a č. 6; Zostava a dosah symbolov v porevolučnom období, s. 106-111.

$4 \mathrm{~V}$ priestore NR SR sa nachádza vitrína s národnými symbolmi a ústavou, busta prvého predsedu SNR Jozefa Miloslava Hurbana, súčasná vlajka Slovenskej republiky a kópia jednej z revolučných zástav. Priestor strážia dvaja vojaci v uniformách slovenských dobrovol'níkov, resp. ich ovela honosnejší vizuál prijatý ako uniforma Čestnej stráže prezidenta SR v 90. rokoch po vzniku samostatnej SR (kabát uniformy vychádza viac zo šlachtického kabáta, mentieky, uhorského šlachtica ako z vojenskej uniformy). Slovenskí dobrovol'níci spočiatku nemali jednotné uniformy. To sa zmenilo, až ked' sa stali súčastou oficiálnej cisárskej armády. Kompletná uniforma sa nezachovala, jej výzor poznáme z viacerých zobrazení slovenských dobrovol'níckych kapitánov. Najznámejším výtvarným dielom je však obraz Jána Francisciho ako dobrovolníckeho kapitána od Petra Michala Bohúňa, z rokov 1849-1850 uložený v Slovenskej národnej galérii, v pravej dolnej časti aj s vyobrazením slovenských dobrovol'níkov. ZUBEREC, Vladimír. Doklady o slovenskom národnorevolučnom hnutí v rokoch 1848-1849 v slovenských múzeách. In Zborník Slovenského národného múzea. História, 
Jozef Miloslav Hurban (predseda), Ludovít Štúr a Michal Miloslav Hodža, hlavné osobnosti národného hnutia v 40. rokoch 19. storočia. Tieto udalosti sa stali súčastou slovenského národného príbehu, ale aj procesu mytologizácie i folklorizácie. Jednotlivé národné koncepcie neboli navzájom kompatibilné a narážali na vzájomné rozpory. ${ }^{5}$

Poznanie a reprezentácia faktov z minulosti sú vždy sprostredkované súčasnostou jednotlivcov a skupín. Pamät je evokáciou a rekonštrukciou minulosti na základe aktuálnych potrieb. Vytvorené kolektívne spomienky z minulosti znižujú rozmanitost' spomienok jednotlivcov a skupín, pričom konštruujú realitu niekol'kých „štruktúrovaných komunít" so spoločnou symbolickou realitou, ktorá je spojená s históriou. Subjektom spomínania je vždy jednotlivec, ktorý konštruuje minulost $\mathrm{v}$ závislosti na rámci organizujúcom jeho spomienky (ktorým je skupinou zdiel’aná predstava ). Tak ako existuje viacero pohladov na určitý historický jav v rámci individuálnej pamäti (vyplývajúca z viacerých faktorov vzdelanostných, ideových, vyplývajúcich z rodinného a lokálneho zázemia a pod.), podobne paralelne prebieha v rámci určitého spoločenstva viacero kolektívnych pamätí, $\mathrm{v}$ prípade národa hovoríme o národnej pamäti. ${ }^{6}$

\footnotetext{
1991, roč. 31, s. 43-48; HOUDEK, Ivan. Bratislava v revolučných rokoch 1848-1849. In Bratislava. Spisy Mestského múzea v Bratislave, zv. 5. Bratislava: Osveta, 1970, s. 191

5 Bližšie napríklad HROCH, Miroslav. Národy nejsou dílem náhody. Př́ičiny a předpoklady utvárení moderních evropských národů. Praha: Slon, 2009, 3. čast', kapitola č. 3 a 5, s. 168-199 a 240-257. Hroch je autorom viacerých publikácií zameraných na formovanie malých národov v tzv. dlhom 19. storočí. Tiež napríklad KREKOVIČ, Eduard, Elena MANNOVÁ a Eva KREKOVIČOVÁ. Mýty naše slovenské. 2. vyd. Bratislava: Premedia, 2013.

6 Bližšie HALBWACHS, Maurice. Kolektivní pamět. Praha: SLON, 2009, s. 124. V slovenskom prípade môžeme napríklad sledovat rozdielne hodnotenie obdobia prvej Slovenskej republiky v rokoch 1939-1945, vnímanie obdobia v rokoch 1948-1989 a pod.
}

Pred rokom 1918, resp. po rakúsko-uhorskom vyrovnaní, na území Uhorska sa oficiálna pamät na revolúciu prezentovala z pohladu mad’arskej politickej reprezentácie. ${ }^{7}$ Väčšina predmetov spojených so slovenskou pamätou na udalosti revolúcie 1848/1849 sa nachádzala v súkromných zbierkach a ich existencia bola známa úzkemu okruhu slovenských l’udí. Dominantnú čast' dokladov o udalostiach revolúcie 1848/1849 tvoria archívne dokumenty, prevažne písomnosti a tlače, a obrazové dokumenty. ${ }^{8}$ V slovenských národoveckých rodinách uchovávali predmety spojené s revolučnými udalosţami. Vieme, že J. M. Hurban si v polovici apríla 1848 kúpil v Bratislave „peknú šablu, troje duplovky krásnych pištolí, krásnu kabelu, pušného prachu, gule atp. " 9 Tieto predmety po ňom získal jeho syn a pokračovatel' Svetozár Hurban Vajanský a sú dnes prevažne vystavené. Zaujímavý osobný predmet J. M. Hurbana, ktorý bol objavený až koncom 80. rokov 20. storočia v rámci osláv 150 . výročia revolúcie, je „orlie pero“ z jeho klobúka noseného počas revolúcie, „potom na pero obrátené, ktorým písal obranné memorialy,

\footnotetext{
7 Napr. HAIDER, Barbara a Hans HYE (eds.). 1848: Ereignis und Erinnerung in den politischen Kulturen Mitteleuropas. Vienna: Verlag der Österreichischen Akademie der Wissenschaften, 2003. 315 s. Zentraleuropa-Studien, zv. 7.

8 ZUBEREC, Vladimír. Doklady o slovenskom národnorevolučnom hnutí v rokoch 1848-1849 v slovenských múzeách. In Zborník Slovenského národného múzea. História, 1991, roč. 31, s. 50-52. $\mathrm{Z}$ obrazových dokumentov patria $\mathrm{k}$ najcennejším dagerotypia 11-člennej slovenskej delegácie k panovníkovi Františkovi Jozefovi v Olomouci 26. 3. 1849, litografie L'. Štúra a J. M. Hurbana od Anastaseho Jovanoviča a portrét J. M. Hurbana od Johanna Bössa z roku 1849. Časṫ týchto dokumentov nachádzame vo forme faksimilií aj v múzejných expozíciách. Bližšie napríklad: MATULA, Vladimír. Matica slovenská a počiatky slovenského múzejníctva. In Matica slovenská v našich dejinách. Bratislava: Slovenská akadémia vied, 1963, s. 124-135; RYBECKÝ, Milan. Muzeálna slovenská spoločnost’ a jej miesto v národnej kultúre. Martin: Osveta, 1983; KODAJOVÁ, Daniela. Úvahy slovenských národovcov o potrebe inštitucionalizovat zbieranie pamiatok minulosti. Muzeológia a kultúrne dedičstvo, 2013, roč. 1, č. 2, s. 10-15; PODUŠELOVÁ, Gabriela a kol. Slovenské národné múzeum. Bratislava: Slovenské národné múzeum, 2013.

9 GOLÁŇ, Karol. Revolučné pokolenie. Myjava: Daniel Pažický, 1926, s. 41.
}

články a historie bojovania nášho“, ako nám zapísal samotný Hurban na priloženom papieri. ${ }^{10}$

Pamiatky spojené so slovenským povstaním počas revolúcie však neopatrovali len predstavitelia národného hnutia, ale nachádzame ich aj vo vtedajších štátnych, resp. uhorských inštitúciách. Ich úlohou malo byt’ zdôrazňovanie vojenských úspechov mad’arskej armády a gardy nad slovenskými dobrovol'níkmi. Napríklad v Župnom múzeu v Nitre uchovávali najväčší súbor upravených kôs používaných slovenskými dobrovolnníkmi. Počas septembrového povstania len malá čast' dobrovol'níkov používala strelné zbrane, ak, tak väčšinou zastarané, preto používali aj prerobené rol’nícke náradie, ako vidly, cepy a upravené kosy. V. Zuberec predpokladá, že tieto kosy boli ukoristené $\mathrm{v}$ bitke pri Senici a spočiatku boli uložené v mestskom archíve v Bratislave. Odtial' ich presunuli do múzea v Nitre, ${ }^{11}$ možno aj z toho dôvodu, že práve v Nitre boli uložené múzejné zbierky zrušenej Matice slovenskej.

Do súčasnosti sa zachovali štyri zástavy slovenské dobrovolnícke zástavy. Dve sa nachádzajú v Múzeu mesta Bratislavy, jedna v Slovenskom národnom múzeu Etnografickom múzeu v Martine (d’alej SNM-EM) a jedna menšia v Literárnom múzeu Slovenskej národnej knižnice v Martine. ${ }^{12}$ Dve dobrovol'nícke, tzv. hurbanovské“ zástavy uložené v Múzeu mesta Bratislavy získali mad’arské národné gardy po vítazstve nad

10 Podrobnejšie o ňom píše ZUBEREC, Vladimír Neznáme doklady z rokov meruôsmych. Múzeum, 1990, roč. 35, č. 4, s. 11-12.

11 ZUBEREC, Vladimír. Doklady o slovenskom národnorevolučnom hnutí v rokoch 1848-1849 v slovenských múzeách. In Zborník Slovenského národného múzea. História, 1991, roč. 31, s. 40-41.

12 ZUBEREC, Vladimír. Doklady o slovenskom národnorevolučnom hnutí v rokoch 1848-1849 v slovenských múzeách. In Zborník Slovenského národného múzea. História, 1991, roč. 31, s. 29-33. Zástava v SNM-EM pochádza zo zbierok Muzeálnej slovenskej spoločnosti. 
slovenskými dobrovolníkmi v bitke pri Senici 26. septembra 1848. Ako trofej sa najprv dostali do mestského archívu a odtial do múzea, ktoré vzniklo v roku $1868 .{ }^{13}$ Originály týchto dvoch zástav nie sú vystavené v múzejnej expozícii. $S$ ich substitútami sa však môžeme stretnút nielen v slovenských múzeách, ale aj vo foyeri slovenského parlamentu. Druhá zo spomínaných zástav (s textom „Svornost" a „Sláva královi a slobode") sa stala symbolom politických zmien po ukončení 1. svetovej vojny a vzniku Československa. Po obsadení Bratislavy, vtedajšieho Prešporka, československým vojskom na Silvestra 1918 sa Bratislava stala súčastou novovznikajúceho Československa a zároveň hlavným mestom Slovenska. Dňa 4. februára 1919 sa do Bratislavy prestahovalo ministerstvo s plnou mocou pre správu Slovenska na čele s ministrom Vavrom Šrobárom (tzv. Šrobárova vláda). Členov ministerstva vítali československí legionári práve s touto zástavou, ako symbolom vojenských tradícií Slovákov a bojov za národnú slobodu.

Slovenská interpretácia revolúcie 1848/1849 sa stala súčastou, oficiálnej, štátnej pamäte po vzniku ČSR v roku 1918. V tomto období bola aj výraznejšia snaha posilňovat historickú pamät na toto obdobie aj prostredníctvom múzejných zbierok a múzejnej prezentácie. V medzivojnovom období, po výstavbe novej budovy SNM v Turčianskom Sv. Martine, tu sprístupnili historickú expozíciu, ktorej súčastou bola aj prezentácia

\footnotetext{
13 HOUDEK, Ivan. Bratislava v revolučných rokoch 1848-1849. In Bratislava. Spisy Mestského múzea v Bratislave, zv. 5. Bratislava: Osveta, 1970, s. 183; ZUBEREC, Vladimír. Doklady o slovenskom národnorevolučnom hnutí v rokoch 1848-1849 v slovenských múzeách. In Zborník Slovenského národného múzea. História, 1991, roč. 31, s. 29. Pôvodne boli tri, jedna, bez textu, sa však nezachovala. Jedna červeno-modro-biela zástava nesie v jednotlivých pruhoch texty: „Bratstvo a svornost"“, „Za krála a národ slovenský“" a „Sláva! Šetkím Slovákom“, druhá má v červenom páse text „Sláva královi a slobode“ a bielom „Svornost" modré pole je bez textu.
}

obdobia revolúcie. ${ }^{14} \mathrm{~V}$ roku 1938 sa však uzatvára síce krátke, ale pre slovenský národný vývoj mimoriadne priaznivé obdobie národnej emancipácie vd’aka demokratickým pomerom prvej ČSR a nastupuje 50-ročné obdobie poznačené totalitným režimom.

\section{Situácia nástupe komunistického režimu v roku 1948}

Po komunistickom prevrate vo februári 1948 a upevnení vedúcej úlohy komunistickej strany sa oficiálnou ideológiou historiografie stal marxizmus-leninizmus. Vládna moc sa sústredovala na rozvoj socialistickej spoločnosti a v rámci nej kultúrnej revolúcii. Osobitne XI. zjazd KSČ z roku 1958 zdôrazňoval dovŕšenie socialistickej revolúcie v Československu aj v oblasti ideológie a kultúry. Spočiatku sa pre obdobie revolúcie zdôrazňoval sociálny aspekt, zrušenie poddanstva a riešenie rolníckej otázky. Celá zložitosţ tohto obdobia sa zjednodušila na dva nezmieritelné póly: pokrokovost' - reakčnost' a revolúcia - kontrarevolúcia. Pohlad na ňu sa interpretoval z pohladu sociálnej revolúcie. Národná otázka bola zatlačená do úzadia a prekrytá zdôrazňovaním socialistického internacionalizmu. ${ }^{15}$ Vtedajšia oficiálna historická pamät tak bola ovplyvňovaná aktuálnym politickým dianím. ${ }^{16}$ Javy a udalosti minulosti boli selektívne vyberané a interpretované $\mathrm{z}$ pohl'adu marxis-

\footnotetext{
14 Podrobnejšie napríklad RYBECKÝ, Milan. Muzeálna slovenská spoločnosṫ a jej miesto v národnej kultúre. Martin: Osveta, 1983, s. 159 a n.; Oddelenie pre slovenskú kultúrno-národnú historiu v Slovenskom národnom muzeu. Casopis Muzeálnej slovenskej spoločnosti, roč. 26, 1934-1935, č. 1, s. 8 a 12-14; Slovenské národné múzeum v Turčianskom Sv. Martine. Sprievodca sbierkami múzea. Turčiansky Sv. Martin: Muzeálna slovenská spoločnost', 1938, s. 10 .

15 ŠKVARNA, Dušan. Obraz rokov 1848/49 v slovenskej kultúre (od polovice 19. storočia po súčasnosṫ). In MACHO, Peter a kol. Revolúcia 1848/49 a historická pamät. Bratislava: Historický ústav Slovenskej akadémie vied, 2012, s. 37-56. 16 BAČOVÁ, Viera. Historická pamät ako zdroj konštruovania identity. In BAČOVÁ, Viera (ed.). Historická pamät' a identita. Košice: Spoločenskovedný ústav Slovenskej akadémie vied, 1996, s. 19.
}

ticko-leninskej interpretácie dejín. Vtedajšia slovenská historiografia sa tak ocitla nad problémom, ako interpretovat toto obdobie, ked’že vtedajšia slovenská politická reprezentácia stála na strane „kontrarevolúcie“.

Vtedajšia oficiálna historiografia hodnotila pôsobenie slovenskej politickej reprezentácie počas revolúcie 1848/1849 ako spoluprácu s „viedenskou reakciou“, resp. „rakúskou kontrarevolúciou“, ked” mad’arská revolúcia bola porazená aj za „aktívnej ozbrojenej účasti slovenských nacionalistov". Hoci „ostáva v tábore mad’arskej revolúcie čast' Slovákov. Na čele druhej časti Slovákov stáli štúrovskí buržoázni politici, ktorí sa nedohodli s vedúcimi mad’arskými kruhmi. Takto sa dostali na pôdu chybnej politiky, na ktorú strhli aj časṫ slovenských ludových vrstiev, predovšetkým rolníctva, nespokojného s nedôsledným „riešením" agrárnej otázky. "17 V duchu novej ideológie sa mali prezentovat aj múzejné expozície, o čom rozhodlo aj Povereníctvo školstva, vied a umení v roku 1951. Túto úlohu v roku 1953 prevzalo novozaložené povereníctvo kultúry. ${ }^{18}$

Jednou z významných činností múzeí v tomto období bola dokumentácia moderných dejín $\mathrm{v}$ československých múzeách, $\mathrm{v}$ dobovej terminológii obdobia kapitalizmu a socializmu. Tej problematike sa koncepčne, aj v teoretickej rovine, od polovice 60. rokov venovala aj Komisia pre dejiny kapitalizmu a socializmu pri Ústrednej múzejnej rade. $\mathrm{Z}$ pohladu marxistickej interpretácie dejín v 50. rokoch bol problém $\mathrm{s}$ hodnotením pôsobenia Slovákov počas revolúcie. Pozitívne

17 DUBNICKÝ, Jaroslav. Revolučné hnutie na Slovensku v rokoch 1848-49. In HOLOTíK, Ludovít (ed.). Dejiny Slovenska. Tézy. Príloha Historického časopisu. Ročník III (1955). Bratislava: Slovenská akadémia vied, 1955, s. 123

18 RYBECKÝ, Milan. Muzeálna slovenská spoločnost' a jej miesto $v$ národnej kultúre. Martin: Osveta, 1983, s. 181 a n.; Expozícia histórie v Slovenskom múzeu. In Historický sborník Slovenského múzea, 1961, roč. 1, s. 93-106. 
sa hodnotila mad’arská revolúcia, naopak, Slováci stáli na strane „kontrarevolúcie“ a „reakcie“ a napomáhali k jej potlačovaniu.

Dôležitou úlohou slovenského múzejníctva tohto obdobia bolo prezentovat slovenskej verejnosti dejiny Slovenska s Slovákov formou múzejnej prezentácie v duchu marxisticko-leninskej ideológie. V budove dnešného SNM - Prírodovedného múzea na Vajanského nábreží v Bratislave, vtedy ešte Slovenského múzea, bola v rokoch 1957 a 1959 sprístupnená nová historická expozícia približujúca dejiny Slovenska od najstarších čias do súčasnosti, t. j. do konca 50. rokov. Pri prezentácii revolúcie 1848/1849 dominoval dôraz na revolučnost', odkaz na Vel'kú francúzsku revolúciu 1789 a revolúcie vo Viedni a Pešti 1848, vojenské operácie a pomoc „ruského cárizmu“ pri potlačení mad’arskej revolúcie. Dominovali obrazové prostriedky - fotokópie dokumentov a obrazov predstavitelov národného hnutia. Autentické predmety predstavovali hlavne zbrane a vtedajšie platidlá, tzv. košútovky. ${ }^{19}$

\section{Múzeum Slovenských národných rád na Myjave}

Aj v tomto období napriek presadzovaniu oficiálnej komunistickej ideológie a z nej vychádzajúcej historickej pamäte na obdobie revolúcie pretrvávalo na regionálnej úrovni rozdielne povedomie o týchto udalostiach, čo sa prejavilo aj v období politického uvolnenia v 60. rokoch a predovšetkým po roku 1989. Ako uvádza M. Halbwachs, ${ }^{20}$ existuje viacero kolektívnych pamätí, čím sa kolektívna pamät odlišuje od histórie, resp. oficiálnej histórie.

\footnotetext{
19 PICHŇA, Ján. Expozícia obdobia kapitalizmu (do r. 1918). In Historický sborník Slovenského múzea, 1961, roč. 1, s. 100. Na začiatku 70. rokov sprístupnili novú expozíciu dejín Slovenska

v zrekonštruovaných priestoroch na Bratislavskom hrade.

20 HALBWACHS, Maurice. Kolektivní pamět. Praha: SLON, 2009, s. 124, 129, 132.
}

História je výber faktov, ktoré zaujali najdôležitejšie miesto $v$ pamäti ludí, všeobecne začína až tam, kde končí tradícia, v okamihu, kde zaniká alebo sa rozkladá sociálna pamät. Ked' sa už pamät nemôže opriet o skupinu, ktorá sa podielala alebo niesla dôsledky daných udalostí či o nich počula z prvej ruky, vtedy je dôvod na ich písomné zaznamenanie.

Práve v podjavorinsko-podbradlianskom regióne, kde sa nachádza aj mesto Myjava, sídlo SNR, ktorá organizovala „boj za národnú slobodu“, pretrvávala sociálna pamät na revolúciu 1848/1849 ešte $v$ 60 . rokoch 20. storočia, t. j. po viac ako storočí. V tomto období tu etnológovia vykonávali folkloristické výskumy, ktoré zachytili spomienky obyvatelov na J. M. Hurbana, a to aj ako vodcu povstania. ${ }^{21}$ Formovanie historickej pamäte je vo výraznej miere utvárané práve pôsobením výnimočných osobností, čo vedie k utváraniu „kultu hrdinov“, ktorí si miesto $\mathrm{v}$ „národnom panteóne" vydobyli svojimi výnimočnými skutkami a ich uctievanie môže prerást̉ až do polohy sakralizácie. V historickej pamäti sú národní hrdinovia vnímaní ako sprostredkovatelia, prostredníci medzi minulostou a prítomnostou. ${ }^{22}$

Už v 20. rokoch 20. storočia bola snaha založit na Myjave Múzeum Hurbanovho povstania. Z týchto snáh sa podarilo jedine osadit pamätnú tabulu na dome pani Kolényovej, kde sídlili členovia SNR, pri príležitosti 80 . výročia zasadnutia prvej SNR v roku 1928. Myšlienka na založenie múzea znova ožila na začiatku 60. rokov zásluhou miestneho rodáka, lokálpatriota a zbe-

\footnotetext{
21 Bližšie MANNOVÁ, Elena. „Meruôsmy“ v médiách spomínania a zabúdania. In MACHO, Peter a kol. Revolúcia 1848/49 a historická pamät. Bratislava: Historický ústav Slovenskej akadémie vied, 2012, s. 19

22 OLEJNÍK, Milan. Základné prvky obsahu historickej pamäti a ich úloha pri formovaní kolektívnej identity. In BAČOVÁ, Viera (ed.). Historická pamät a identita. Košice: Spoločenskovedný ústav Slovenskej akadémie vied, 1996, s. 42-54.
}

ratel’a Jána Bradáča, ktorý si vo svojom dome stojacom vedla domu pani Kolényovej uložil svoju zbierku. Vd’aka záujmu miestnych obyvatel'ov mesto odkúpilo dom pani Kolényovej a zriadilo v ňom múzeum. ${ }^{23}$ Jeho kustódom sa stal J. Bradáč, ktorý múzeu venoval aj svoje rozsiahle zbierky. Práve J. Bradáč je jedným z mnohých lokálnych osobností, nositelov individuálnych pamätí, odlišných od oficiálnej historickej pamäte, ked' sa generačnou transmisiou zabezpečuje kultúrna kontinuita danej spoločnosti.

Na vzniku múzea sa pozitívne podielali hlavne dva faktory: okrúhle výročie založenia prvej (1848) i druhej SNR (1918) a politické uvol'ňovanie $\mathrm{v} 60$. rokoch, ktoré vyvrcholilo tzv. Pražskou jarou v roku 1968. Druhá SNR vznikla 30. 10. $1918 \mathrm{v}$ Martine na konci 1. svetovej vojny a jej členovia podporili vznik Československej republiky. V tomto období sa pomaly začal menit pohlad na historické udalosti, v 50. rokoch zviazané marxisticko-leninskou interpretáciou. Prejavilo sa to aj v oblasti múzejníctva. Hoci vtedajšie politické vedenie na čele s prvým tajomníkom KSČ a prezidentom Antonínom Novotným nebolo naklonené rozvoju národno-emancipačných snáh Slovákov, politický odmäk prispel k jeho rozmachu a narúšaniu oficiálnej historickej pamäte na jednotlivé historické medzníky moderných dejín zošnurované marxisticko-leninskou ideológiou. V roku 1965 sa vedenie mesta Myjava obrátilo so žiadostou na vtedajšieho predsedu SNR Michala Chudíka o založenie Múzea revolučného roku 1848 na Myjave, ktorý túto snahu podporil. ${ }^{24} \mathrm{~V}$ roku 1965 tak vzniklo nové múzeum na

23 LANDOVÁ, Blanka. Dvadsat rokov Múzea slo venských národných rád. Múzeum, 1988, roč. 33, č. 3 , s. $54-57$.

24 Archív Slovenského národného múzea v Bratislave (d’alej ASNM), rok 1968. Predseda SNR Michal Chudík povereníkovi SNR pre financie Františkovi Hagarovi, 16. 7. 1965. Žiadost̉ o založenie Múzea revolučného roku 1848 na Myjave. 
Myjave, spojenej s pôsobením prvej SNR z roku 1848 a septembrovým povstaním. Múzeum síce pôvodne vzniklo ako mestské, jeho predstavitelia však mali od počiatku snahu sústred'ovat' sa na obdobie septembrového povstania a pôsobenia SNR na Myjave a okolí a pripravit expozíciu k 120. výročiu tejto udalosti. V pôvodnom štatúte z roku 1965 sa ešte osobitne nespomína špecializácia na SNR. ${ }^{25}$

Múzeum si napokon politicky vzalo pod patronát Predsedníctvo SNR, ktoré 30. marca 1966 prijalo uznesenie č. 52, že v rámci osláv 120. výročia založenia SNR sa má v roku 1968 sprístupnit na Myjave Múzeum - pamätník SNR ako súčasť špecializovaného mestského múzea. ${ }^{26}$ Napokon sa zameranie pripravovanej expozície rozšírilo na pôsobenie SNR v troch zlomových historických obdobiach: počas revolúcie 1848/1849, na konci 1 . svetovej vojny a v období 2 . svetovej vojny (1943). Otvoreniu múzea napomáhali aj okrúhle výročia: 120 ., 50. a 25. výročie založenia jednotlivých národných rád.

Múzeum od počiatkov spolupracovalo so SNM - Historickým múzeom (d’alej SNM-HM), preto vedenie SNM predložilo 4. 10. 1967 Povereníctvu SNR pre kultúru a informácie návrh, aby múzeum bolo začlenené do štruktúry SNM. Zároveň sa do konca roka 1967 ustálilo jeho oficiálne pomenovanie. ${ }^{27}$ Tak napokon vzniká nové špecializované múzeum - Múzeum slovenských národných rád na Myjave. Múzeum slávnostne sprístupnili verejnosti 21. septembra 1968 za osobnej účasti vtedajšieho predsedu SNR Ondreja Klokoča. ${ }^{28}$ Sídlilo a dodnes

25 ASNM, rok 1968. Návrh štatútu Mestského múzea na Myjave, 20. 5. 1965.

26 KOSTICKÝ, Bohuš. Nové múzeum na Myjave. Múzeum, 1967, roč. 12, č. 1, s. 56-57.

27 ASNM, rok 1968. Záznam z kontrolného dňa na stavbe múzea na Myjave zo dňa 20. X. 1967 napísaný na MsNV Myjava.

28 LANDOVÁ, Blanka. Dvadsat̉ rokov Múzea slovenských národných rád. Múzeum, 1988, roč. 33, č. 3 , s. 56 sídli v dome, kde v septembri 1848 zasadala prvá Slovenská národná rada a počas revolúcie ho vlastnila rodina Kolényovcov. SNR tiež súhlasila s konzerváciou a pamiatkovou obnovou domu a prístavbou pamätníka SNR na Myjave „ako pamätníka Slovenskej národnej rady celoslovenského a celoštátneho významu“ ${ }^{29}$ Rekonštrukcia objektu a dostavba novej funkčnej budovy múzea podla projektu Ing. arch. Martina Kusého prebehla v rokoch 1966-1968. Dôvod na založenie múzea uviedol autor libreta a scenára B. Kostický nasledovne: „Základným mottom múzea - pamätníka je muzeálne a architektonické vyjadrenie myšlienky: $v$ revolučných a prelomových dobách stál na čele slovenského ludu vždy autoritatívny národný orgán - Slovenská národná rada - ktorý vyjadroval a uskutočňoval vôlu slovenského národa po vlastnom živote $v$ bratskej spolupráci s českým národom a so silami demokracie a pokroku. “30 $\mathrm{Z}$ tejto tézy už nie je d'aleko na postupné rozšírenie zamerania múzea nielen na prvú SNR, ale aj d’alšie národné rady, vrátane druhej, založenej na martinskom zhromaždení 30. októbra 1918 a 3. SNR, ktorá vznikla v roku 1943 a organizovala protifašistické Slovenské národné povstanie v roku 1944.

Prijatý múzejný koncept počítal s tým, že v autentických priestoroch pôvodného domu Kolényovcov bude národopisná expozícia, činnost̉ slovenských národných rád zasa $v$ rozšírených výstavných priestoroch $\mathrm{v}$ novom múzejnom pavilóne. ${ }^{31}$ Pracovníci SNM-HM si kládli za ciel’ poskytnút návštevníkom objektívny a neskreslený pohlad na tieto dejinné udalosti,

\footnotetext{
29 ASNM, rok 1968. Povereníctvo SNR pre školstvo a kultúru v Bratislave: Schval'ovací protokol, 2. 12.1966.

30 KOSTICKÝ, Bohuš. Nové múzeum na Myjave. Múzeum, 1967, roč. 12, č. 1, s. 57.

31 LANDOVÁ, Blanka. Dvadsat̉ rokov Múzea slovenských národných rád. Múzeum, 1988, roč. 33, č. 3, s. 54-57. Autorom scenára a libreta bol Bohuš Kostický.
}

očistené od nánosov stalinskej ideologizácie, ako sa uvádza aj v návrhu scenára: „...Vplyvom deformácií obrazu týchto uzlových udalostí $v$ dávnejšej i nedávnej minulosti neboli ony náležite zhodnocované (ba boli často i znehodnocované) a ich politický dosah sa preto nemohol náležite využívat pri upevňovaní národného povedomia. $Z$ nedostatočného poznania našich národných dejín dostávala i naša verejnost matný, ba neraz i pasívny obraz o celonárodných úsiliach. Slovenský národ javil sa potom ako politicky nezrelý, neistý si so svojim postavením $v$ rodine národov a štátov, skôr ako predmet než podmet historického diania. ... Výročia $v$ r. 1968 poskytujú nám mimoriadnu príležitost' rehabilitovat' spomínané udalosti, ich ciele, výsledky i poučenia z nich a súčasne preniknút's tymito uzávermi do vedomia širokých vrstiev nášho l’udu...“"32

\section{Obdobie normalizácie}

Samotné otvorenie nového múzea však už bolo poznačené udalostami po okupácii Československa vojskami Varšavskej zmluvy v auguste 1968, čo sa prejavilo postupným procesom tzv. „normalizácie“,

t. j. „návratu“ politickej situácie spred Pražskej jari. Tento proces zasiahol aj expozíciu múzea. Už v roku 1974, t. j. po šiestich rokoch, pri príležitosti 30 . výročia Slovenského národného povstania, prešlo Múzeum Slovenských národných rád reinštaláciou. Táto, na slovenské pomery rýchla úprava múzejnej expozície, nebola primárne ovplyvnená múzejnými potrebami, ale práve zmenou politickej klímy nastupujúcej normalizácie. V zdôvodnení reinštalácie sa uvádza: „...Primárny je ten, že doterajšia expozícia preceňovala úlohu zahraničného odboja a II. SNR pre osudy slovenského národa, kým III. SNR - nepochybne najvýznamnejšia - bola zatlače-

\footnotetext{
32 ASNM, rok 1968. SNM-Múzeum slovenských národných rád. Návrh scenára pre stálu tematickú výstavu. Spracoval: Bohuš Kostický. Bratislava máj-júl 1967.
} 
ná do úzadia. Aj pri interpretácii úlohy I. SNR sa často uplatňovali dokumenty zvádzajúce k falošným hodnoteniam. Autori (doterajšieho) scenára ... chceli problematiku interpretovat'v čo najhutnejšej skratke a bez vysvetlujúcich textov, ... (ale) inštalované exponáty umožňovali širokú stupnicu výkladov. ... V najbližšej budúcnosti však treba uvažovat'o základnej reinštalácii expozície (podčiarkol L. K.), pri ktorej by sa pozmenila aj jej koncepcia. ${ }^{\text {33 }} \mathrm{V}$ rámci reinštalácie sa najvýraznejšie upravila čast̉ expozície venovaná druhej a tretej SNR z rokov 19181919 a $1943-1945 .{ }^{34}$

Inými slovami: „Nová expozícia Múzea SNR odlišuje sa od doterajšej jednak takmer novým materiálom, jednak korektúrou koncepcie (podčiarkol L'. K.), hoci jej základný zámer - zobrazenie troch Slovenských národných rád ako reprezentantov národnej svojbytnosti, tlmočiacich záujmy a vôlu celého národa $v$ prelomových fázach jeho vývinu - zostal. “35 Kým v pôvodnej expozícii dominovalo pôsobenie 1 . SNR, v reinštalácii sa zvýraznila činnost 3 . SNR počas 2 . svetovej vojny s posilnením významu komunistického protifašistického odboja. Pôsobenie 1 . SNR sa prezentovalo „v širokom kontexte boja za sociálne a emocionálne práva slovenského národa $v$ duchu buržoáznej revolúcie... (pričom) ...expozícia umožňuje vernú a ideovo správnu interpretáciu tejto zložitej problematiky (podčiarkol L. K.).“ ${ }^{36} \mathrm{Z}$ národného kontextu sa teda podobne ako v 50. rokoch vo výraznejšej miere zdôrazňoval boj „ludových más“ za sociálnu, ako národnú slobodu. Základ múzejnej prezentácie tvorili faksimile poli-

33 ASNM, rok 1968. SNM-Múzeum slovenských národných rád. Scenár expozície z roku 1974

34 LANDOVÁ, Blanka. Dvadsat rokov Múzea slovenských národných rád. Múzeum, 1988, roč. 33, č. 3, s. 56. Autormi reinštalácie boli Ludovít Haraksim a Vladimír Zuberec.

35 -vz-. Múzeum SNR v Myjave k 30. výročiu Slovenského národného povstania. Múzeum, 1974, roč. 19, č. 4 , s. 117.

36 Tamže, s. 117. tických dokumentov a fotografie obrazových dokumentov, doplnené trojrozmernými predmetmi, ako pečatidlo SNR, zástava a zbrane slovenských dobrovol’níkov.

Napriek zmene politickej situácie v 70. rokoch, pohl'ad oficiálnej historiografie sa nevrátil do 50 . rokov a pôsobenie Slovákov období revolúcie je už $\mathrm{v}$ učebniciach dejepisu zo 70. a 80. rokov zhodnotené objektívnejšie: „Slovenské povstanie ... i pri všetkých svojich neúspechoch a nedostatkoch (orientácia na reakčnú viedenskú vládu) ... malo v dejinách slovenského národa mimoriadne vážny a d’alekosiahly význam. $\mathrm{Na}$ prelome dvoch vekov Slováci postrehli nevyhnutnost' spoločenského pokroku a vystúpili s hlboko demokratickým programom, ktorý svojím obsahom sledoval $v$ dovtedy najvyššej miere zlepšenie postavenia bezprávneho slovenského l'udu. $V$ boji o svoje oslobodenie z národnostného útlaku, úzko spojené so sociálnym útlakom, po bezvýslednosti politického zápasu neváhali siahnut po zbrani a obetovat' i svoje životy. Tak sa slovenské národnodemokratické hnutie $v$ rokoch 1848-1849 stalo jednou zo základných kapitol revolučných tradícií našich národných dejín a spojilo náš národný vývin s celkovým novodobým pokrokovým spoločenským vývinom...."37

O tom, že múzeum slúžilo ako významný ideovo-politický nástroj vtedajšieho režimu, svedčí záujem najvyšších politických predstavitelov Slovenska. Pri následných osmičkových výročiach $\mathrm{v}$ rokoch 1988, 1998 a 2008 - s výnimkou roku 2018 - dochádzalo k pravidelným reinštaláciám. ${ }^{38}$ Od druhej polovice 80. rokov sa pod vplyvom situácie v Sovietskom zväze po nástupe Michaila Gorbačova začína

\footnotetext{
37 Dejiny Československa. Učebné texty pre 3. a 4. ročník gymnázia a pre 2. ročník strednej odbornej školy. 5. vyd. Bratislava: Slovenské pedagogické nakladatel'stvo, 1980, s. 208.

38 LANDOVÁ, Blanka. Nová expozícia Múzea SNR na Myjave. Múzeum, 1989, roč. 34, č. 1, s. $72-73$.
}

opätovné politické uvolňnovanie. V roku 1988, roku osláv 70. výročia ČSR, sa začínajú prehodnocovat' udalosti z rokov 1848 a 1918: „(rok 1848), kedy sa slovenský l'ud po prvý raz $v$ histórii chopil zbraní, aby si vybojoval národné, politické, hospodárske a kultúrne práva“, rok 1918, kedy „vznikol prvý moderný spoločný štát Čechov a Slovákov" a rok 1948, kedy „,̌eský a slovenský lud definitívne porazil buržoáziu a otvoril brány budovania socialistickej spoločnosti dokorán“. ${ }^{39}$ Stále je tak zachovaný ideologický rámec v duchu marxisticko-leninského svetonázoru od prvotných nenaplnených snáh o sociálnej a národnej rovnoprávnosti počas revolúcie 1848/1849, cez naplnenie národných požiadaviek vznikom Československa až po (deklarovanú) sociálnu rovnosť získanú Februárom 1948.

V septembri 1988 sprístupnili novú expozíciu Múzea SNR. Autorom scenára venovaného 1 . a 2 . SNR je historik Vladimír Zuberec, ktorý $\mathrm{v}$ rámci prípravy scenára vykonal rozsiahly výskum v slovenských múzeách. Podarilo sa mu objavit nové predmety viažuce sa $\mathrm{k}$ obdobiu revolúcie, ${ }^{40}$ niektoré z nich vystavili aj v múzejnej expozícii. Čast' vyhradená 1 . SNR bola prezentovaná do šiestich celkov. V úvodnej časti sa nachádzali lepty L'. Štúra, J. M. Hurbana a M. M. Hodžu ako dominantných osobností štúrovského hnutia. Napriek tomu, že predsedom SNR bol Hurban, ktorý bol tiež počas revolúcie vnímaný ako hlavný organizátor slovenského dobrovolníckeho vojska (hurbanisti, Hurbanovo vojsko), portrét L. Štúra bol väčší „ako symbol slovenského národnopolitického hnutia

39 ZUBEREC, Vladimír. Rok významných jubileí. In Zborník Slovenského národného múzea. História, 1988 , roč. 28 , s. 5

40 ZUBEREC, Vladimír. Doklady o slovenskom národnorevolučnom hnutí v rokoch 1848-1849 v slovenských múzeách. In Zborník Slovenského národného múzea. História, 1991, roč. 31, s. 27-61; ZUBEREC, Vladimír. Neznáme doklady z rokov meruôsmych. Múzeum, 1990, roč. 35, č. 4, s. $10-12$. 
od 30-tych rokov 19. stor.“. ${ }^{41}$ Základ expozície tvorili výstavné panely so zobrazením priebehu slovenských dobrovol’níckych výprav, významných politických dokumentov a politických osobností a litografie slovenských dobrovolníkov, doplnené kópiami uniforiem dobrovolníkov. $\mathrm{Z}$ autentických predmetov tu boli tu vystavené pečatidlo SNR, kokarda dobrovolníka a pištol' a „orlie pero“ J. M. Hurbana. Musíme zdôraznit,' že táto čast expozície bola inštalovaná v autentických priestoroch domu, kde zasadali členovia SNR. Tzv. predná izba mala charakter národopisnej expozície, zariadenej dobovým, aj ked' nepôvodným zariadením, aby si návštevník urobil predstavu, ako asi vyzeral tento obytný priestor v polovici 19. storočia. Autentickým predmetom je však stôl, okolo ktorého sedávali členovia SNR a na ktorom podpisovali dokumenty.

\section{Situácia po roku 1989}

Nový pohlad na interpretáciu moderných slovenských dejín 19. a 20. storočia priniesli politické zmeny v roku 1989. Bola zrušená expozícia dejín Slovenska na Bratislavskom hrade, poznačená marxisticko-leninskou ideológiou, ktorá ani v súčasnosti, takmer po tridsiatich rokoch, nie je nahradená novou expozíciou. Reinštaláciami prešla expozícia SNM - Múzea slovenských národných rád na Myjave v roku 1998 i 2008. V roku 1992 bolo založené Literárne múzeum Slovenskej národnej knižnice v Martine. ${ }^{42}$ V expozícii sú pred-

41 LANDOVÁ, Blanka. Nová expozícia Múzea SNR na Myjave. Múzeum, 1989, roč. 34, č. 1, s. $72-73$.

42 Pôvodný názov múzea bol Slovenské národné literárne múzeum a spravovala ho Matica slovenská. Snaha o založenie múzea - ako Pamätník národného písomníctva siaha do 60. rokov 20. storočia. Čast venovaná literárnym tradíciám tzv. dlhého 19. storočia (1780-1918), teda vrátane štúrovského hnutia, bola sprístupnená v roku 1994. Podrobnejšie o múzeu napríklad: KIANIČKA, Lubomír. Celoslovenská literárnomúzejná expozícia v Slovenskom národnom literárnom múzeu MS v Martine. Múzeum, 1998, roč. 43, č. 4, s. $20-21$. stavení literárne činní príslušníci štúrovskej generácie, z ktorých sa výrazná čast̉ aktívne zapojila do povstania. Každá z osobností je predstavená formou medailónu. Na paneli je okrem základných biografických údajov, portrétu, fotokópií miest spojených s pobytom a dobového vydania literárneho diela inštalovaný aj osobný predmet spojený s danou osobnostou. Pri J. M. Hurbanovi je o. i. inštalované aj „orlie pero“ spojené s pôsobením počas revolúcie. Táto čast̉ expozície je pri formovaní historickej pamäte návštevníkov postavená na pôsobení výnimočných osobností, v duchu vyššie spomínaného utváraniu „kultu hrdinov“.

\section{Od 90. rokov sa vo výraznejšej} miere rozvíjajú lokálne múzejné zariadenia, pamätné izby či pamätné domy venované významným miestnym osobnostiam. $\mathrm{V}$ roku 1996 v Sučanoch odhalili Pamätnú izbu Juraja Langsfelda $v$ jeho rodnom dome. Skladá sa z troch častí, ktoré približujú dejiny Sučian, obdobie rokov $1848 / 1849$ vo vztahu k regiónu Turca a Sučian s dôrazom na J. Langsfelda. Tretiu čast tvorí priblíženie d’alších významných osobností spojených so Sučanmi (napr. Milana Hodžu). V expozícii je o. i. vystavená aj košela J. Langsfelda ako najcennejší exponát. ${ }^{43}$ Obec tu každoročne pripravuje spomienkové podujatia pri príležitosti výročia narodenia J. Langsfelda a d’alšieho rodáka, medzivojnového československého premiéra Milana Hodžu, ktorému je tiež venovaná vel'ká čast̉ expozície. ${ }^{44}$

V roku 2008 sprístupnili v SNM Múzeum Slovenských národných rád na Myjave novú expozíciu

\footnotetext{
43 GORELČÍKOVÁ, L’ubica. Pamätný dom Juraja Langsfelda v Sučanoch. Múzeum, roč. 42, 1997, č. 1, s. 14. Koncepciu expozície pripravili literárni muzeológovia prof. Imrich Sedlák a Dr. Jozef Beňovský.

44 Obec sa zapája aj do každoročného podujatia Dni Milana Hodžu (konajú sa od roku 2005), v rámci ktorého sa konajú oslavy v tunajšej pamätnej izbe.
}

s názvom Jar národov zameranú na pôsobenie 1 . SNR. ${ }^{45}$ Zbierkové predmety pochádzajú zo zbierok SNM, alebo zapožičané z iných múzeí (Múzeum mesta Bratislavy, Slovenské banské múzeum v Banskej Štiavnici a Literárneho múzea Slovenskej národnej knižnice v Martine). Sú tu teda sústredené originálne zbierkové predmety spojené s revolúciou 1848/1849 v rámci celoslovenského špecializovaného múzea spravovaného SNM.

Hned' $\mathrm{v}$ úvodnej miestnosti je predstavený J. M. Hurban ako prvý predseda SNR. Nainštalovaný je tu tiež stôl s lavicou, za ktorým sedávali členovia SNR a podpisovali nariadenia, v rohu sú inštalované zbrane slovenských dobrovol'níkov. Nachádza sa tu Hurbanov portrét od J. Bössa, „orlie pero“, jeho puška, ktorú používal v rokoch 1848/1849 a slávnostná šerpa od myjavských Slovákov. Tento „Hurbanov kútik“, zameraný na jeho pôsobenie počas revolúcie 1848/1849 a ako prvého predsedu Slovenskej národnej rady, dopíňajú obrazy slovenských dobrovol'níkov, hurbanistov, z obdobia revolúcie od Josepha Heickeho.

V expozícii sú predstavené výrazné slovenské osobnosti z obdobia revolúcie 1848/1849, z ktorých dominantnú čast̃ tvorili príslušníci štúrovskej generácie, celkovo 20 osobností. Základ tvorí portrét osobnosti (obraz, fotografia), základný biografický popis a trojrozmerný predmet s ňou spojený. Žial', pri väčšine vystavených predmetoch chýba popis, resp. príbeh spojený s vystaveným predmetom, čo by mal byṫ už dnes štandard. Neznalému návštevníkovi tak nie je vždy jasné, či vystavený predmet súvisí s revolúciou, alebo s povolaním danej osobnosti. Tento príbeh sa dozvedáme len pri L. Štúrovi (vystavená čast̉ kosti s gul'kou, odobratá pri pitve, ked’ Štúr zomrel

45 Autormi scenára sú Dušan Kováč, Eva Králiková a Rastislav Púdelka. 
na následky zranenia pri pol'ovačke) a J. M. Hurbanovi (vyššie spomínané tzv. „orlie pero“). Tiež je problém, že nie je jasné, či sú vystavené predmety originály, alebo kópie. Spomínané Hurbanovo „orlie pero" nájdeme vystavené aj v Literárnom múzeu SNK v Martine. Podobne je tu vystavená aj „cifrovaná valaška“ básnika Sama Chalupku, ktorá je vystavená aj v jeho Pamätnej izbe v Hornej Lehote. Tieto „drobnosti“ iste neujdú pozornému návštevníkovi a oprávnene sa môže cítit’ oklamaný, ak sa dozvie, že nevidel originál.

Historické múzeá ako zhmotnená forma historickej pamäte sú súčastou formovania vonkajšej, sociálnej pamäte, nástrojom pri hl'adaní svojej identity, pri nachádzaní vrstiev minulosti, ktoré poskytujú legitímnost' tomu, čo sa deje dnes a jednak sú projektom toho, čo sa má diat' v budúcnosti. Identita nie je jednotlivcovi daná, ale musí sa aktívne tvorit, aj prostredníctvom múzeí. Prostredníctvom historickej kolektívnej pamäti spoločenstvo v každej generácii spoznáva a definuje samé seba. Vyjadruje to pripomínaním, interpretáciou a reinterpretáciou, oslavovaním spoločnej minulosti. Na jednej strane sa usiluje sa o kontinuitu s minulostou, ale zároveň aj selektuje javy, ku ktorým sa z minulosti hlási. ${ }^{46}$ Formovanie historickej pamäti o revolúcii 1848/1849 je výrazne ovplyvnené procesmi diskontinuity vyplývajúcej z politického režimu na území Československa, čo sa prejavilo aj v múzejnej prezentácii. Autormi scenára expozície Múzea SNR boli renomovaní historici pôsobiaci v SNM. Ich múzejná prezentácia však bola determinovaná aktuálnou politickou situáciou a nemohli prekročit limity vtedajšej ideologickej interpretácie daného historického obdobia. Mú-

46 BAČOVÁ, Viera. Historická pamät ako zdroj konštruovania identity. In BAČOVÁ, Viera (ed.). Historická pamät' a identita. Košice: Spoločenskovedný ústav Slovenskej akadémie vied, 1996, s. 14-15. zejná prezentácia tak kopíruje oficiálnu historickú pamät v 50.-90. rokoch 20. storočia. Tá však nebola dostatočne ukotvená v slovenskej spoločnosti a tvorila len akúsi škrupinu, pod ktorou sa ukrývali d’alšie lokálne a individuálne pamäte, ktoré sa však pri oslabení ideologického tlaku zo strany štátu stávali dominantnými. V 20. storočí sa tak pri cca 20-ročných cykloch spojených s ideologickými zmenami permanentne udržiavalo $\mathrm{v}$ spoločnosti viacero kolektívnych pamätí, ktoré prispievali k uchovávaniu generačnej transmisie. Návrat $\mathrm{k}$ historickým tradíciám zažíva na Slovensku svoju renesanciu po roku 1989, je však výrazne politicky i nacionálne podfarbený. Na jednej strane sú historické udalosti zdrojom národnej hrdosti a podnetov národného sebauvedomovania, ale aj nástrojom historickej manipulácie, resp. mýtizácie národných dejín.

\section{LITERATÚRA A PRAMENE:}

Archív Slovenského národného múzea v Bratislave (ASNM), rok 1968.

BAČOVÁ, Viera (ed.). Historická pamät’ a identita. Košice: Spoločenskovedný ústav Slovenskej akadémie vied, 1996. 264 s. ISBN 80-967621-0-9.

Dejiny Československa. Učebné texty pre 3. a 4. ročník gymnázia a pre 2. ročník strednej odbornej školy. 5. vyd. Bratislava: Slovenské pedagogické nakladatel'stvo, 1980.

DUBNICKÝ, Jaroslav. Revolučné hnutie na Slovensku v rokoch 1848-49. In HOLOTíK, L’udovít (ed.). Dejiny Slovenska. Tézy. Príloha Historického časopisu. Ročník III (1955). Bratislava: Slovenská akadémia vied, 1955, s. 115-123.

GOLÁŇ, Karol. Revolučné pokolenie. Myjava: Daniel Pažický, 1926.

GORELČÍKOVÁ, L’ubica. Pamätný dom Juraja Langsfelda v Sučanoch. Múzeum, 1997, roč. 42, č. 1, s. 14.

HALBWACHS, Maurice. Kolektivní pamět. Praha: SLON, 2009, s. 289. ISBN 978-80-7419-016-2.
HAIDER, Barbara a Hans HYE (eds.). 1848: Ereignis und Erinnerung in den politischen Kulturen Mitteleuropas. Vienna: Verlag der Österreichischen Akademie der Wissenschaften, 2003, 315 s. Zentraleuropa-Studien, zv. 7.

Historický sborník Slovenského múzea, 1961, roč. 1, s. 93-106.

HOUDEK, Ivan. Bratislava v revolučných rokoch 1848-1849. In Bratislava. Spisy Mestského múzea v Bratislave, zv. 5. Bratislava: Osveta, 1970, s. 169-199.

HROCH, Miroslav. Národy nejsou dílem náhody. Př́íciny a předpoklady utváření moderních evropských národů. Praha: Slon, 2009. ISBN 978-80-7419-010-0.

KIANIČKA, L’ubomír. Celoslovenská literárnomúzejná expozícia v Slovenskom národnom literárnom múzeu MS v Martine. Múzeum, 1998, roč. 43, č. 4, s. 20-21.

KODAJOVÁ, Daniela. Úvahy slovenských národovcov o potrebe inštitucionalizovat’ zbieranie pamiatok minulosti. Muzeológia a kultúrne dedičstvo, 2013, roč. 1, č. 2, s. 10-15.

KOSTICKÝ, Bohuš. Nové múzeum na Myjave. Múzeum, 1967, roč. 12, č. 1, s. 56-57. KREKOVIČ, Eduard, Elena MANNOVÁ a Eva KREKOVIČOVÁ. Mýty naše slovenské. 2. vyd. Bratislava: Premedia, 2013.

LANDOVÁ, Blanka. Dvadsat̉ rokov Múzea slovenských národných rád. Múzeum, 1988, roč. 33, č. 3, s. 54-57.

LANDOVÁ, Blanka. Nová expozícia Múzea SNR na Myjave. Múzeum, 1989, roč. 34, č. 1, s. 72-73.

MACHO, Peter a kol. Revolúcia 1848/49 a historická pamät. Bratislava: Historický ústav Slovenskej akadémie vied, 2012. 306 s. ISBN 978-80-89396-19-1.

Matica slovenská v našich dejinách. Bratislava: Slovenská akadémia vied, 1963.

Oddelenie pre slovenskú kultúrno-národnú historiu v Slovenskom národnom muzeu. Časopis Muzeálnej slovenskej spoločnosti, 1934-1935, roč. 26, č. 1, s. 7-21.

PODUŠELOVÁ, Gabriela a kol. Slovenské národné múzeum. Bratislava: Slovenské národné múzeum, 2013.

PROFANTOVÁ, Zuzana (ed.). Gramatika národného mýtu a folklór. Bratislava: Ústav etnológie Slovenskej akadémie vied, 1998. 104 s. ISBN 80-968022-5-9.

RYBECKÝ, Milan. Muzeálna slovenská spoločnost' a jej miesto v národnej kultúre. Martin: Osveta, 1983. 
Slovenské národné múzeum v Turčianskom Sv. Martine. Sprievodca sbierkami múzea.

ŠKVARNA, Dušan. Začiatky moderných slovenských symbolov. $K$ vytváraniu národnej identity od konca 18. do polovice 19. storočia. Banská Bystrica: Univerzita Mateja Bela, Fakulta humanitných vied, 2004. ISBN 80-8083-014-2.

-vz-. Múzeum SNR v Myjave k 30. výročiu Slovenského národného povstania. Múzeum, 1974, roč. 19, č. 4, s. 117-119.

ZUBEREC, Vladimír. Rok významných jubileí. In Zborník Slovenského národného múzea. História, 1988, roč. 28, s. 5-10.

ZUBEREC, Vladimír. Neznáme doklady z rokov meruôsmych. Múzeum, 1990, roč. 35 , č. 4 , s. $10-12$.

ZUBEREC, Vladimír. Doklady o slovenskom národnorevolučnom hnutí $\mathrm{v}$ rokoch 1848-1849 v slovenských múzeách. In Zborník Slovenského národného múzea. História, 1991, roč. 31, s. 27-61.

\section{L'UBOŠ KAČíREK}

Katedra etnológie a muzeológie, Filozofická fakulta,

Univerzita Komenského v Bratislave, Slovenská republika

lubos.kacirek@uniba.sk

L’uboš Kačírek vyštudoval odbor slovenský jazyk a literatúra - história a externé rozširujúce štúdium muzeológie na Filozofickej fakulte Univerzity Komenského v Bratislave, dizertačnú prácu v odbore slovenské dejiny obhájil v Historickom ústave Slovenskej akadémie vied v Bratislave. Po ukončení magisterského štúdia pracoval v Múzeu mesta Bratislavy, neskôr na Katedre histórie Pedagogickej fakulty UK v Bratislave. Od roku 2008 pôsobí na Katedre etnológie a muzeológie FiF UK v Bratislave. Venuje sa slovenským dejinám

v 19. a 20. storočí, osobitne dejinám múzejníctva a kultúrnemu dedičstvu v širšom kontexte.
Luboš Kačírek completed the study of Slovak Language and Literature - History and an external course in museology at the Faculty of Arts of Komenský University in Bratislava. He defended his dissertation thesis on Slovak history at the Institute of History of the Slovak Academy of Science in Bratislava. After graduation he worked in the Museum of the City of Bratislava, and later at the Department of History of the Pedagogical Faculty of Komenský University in Bratislava. Since 2008 he has been working at the Department of Ethnology and Museology of the Faculty of Arts of Komenský University in Bratislava. He specialises in Slovak history in the 19th and 20th centuries, focusing on the history of museology and cultural heritage in a broad context. 